\title{
ANALISIS KEMAMPUAN BERFIKIR NALAR MATEMATIS SERTA KONTRIBUSINYA TERHADAP PRESTASI BELAJAR MAHASISWA (Studi Terhadap Mahasiswa FKIP Pendidikan Matematika Universitas Siliwangi)
}

\author{
A.A. Gde. Somatanaya \\ Program Studi Pendidikan Matematika, FKIP, Universitas Siliwangi \\ e-mail: somatanaya@yahoo.co.id
}

\begin{abstract}
ABSTRAK
Berpikir nalar matematis adalah salah satu kemampuan utama yang perlu dimiliki dan merupakan fitrah dari manusia. Melalui berpikir nalarnya manusia terus berkembang dan meningkatkan kemampuan dalam beradaptasi dengan lingkungan yang dinamis dan berubah secara kontinu serta dapat berkreasi dan menciptakan teknologi yang dapat mempermudah kehidupannya. Manusia selalu berpikir serta melalui daya nalarnya dapat membedakan suatu argumen valid maupun invalid. Semakin tajam daya nalar seseorang maka ia akan semakin mampu menghadapi tantangan hidup. Penelitian ini bertujuan untuk mengetahui kemampuan berpikir nalar matematis dan mengetahui indeks prestasi belajar mahasiswa program studi pendidikan matematika serta mengetahui hubungan fungsional dan kontribusi kemampuan nalar matematis terhadap indeks prestasi belajar mahasiswa. Subjek penelitian diambil secara purposive random sampling, instrumennya adalah tes kemampuan berpikir nalar matematis. Data yang didapat dari tes dan dokumentasi dianalisis menggunakan software SPSS Versi 20. Kesimpulannya adalah Kemampuan Berfikir Nalar Matematis tergolong baik, Indeks Prestasi Komulatif mahasiswa pendidikan matematika tergolong sangat memuaskan dan Kontribusinya kemampuan nalar matematis terhadap Prestasi Belajar Mahasiswa tergolong sangat tinggi.
\end{abstract}

Kata Kunci : Berfikir nalar matematis, prestasi belajar 


\section{PENDAHULUAN}

Matematika mempunyai peranan penting dalam proses pendidikan, karena matematika merupakan pondasi yang melandasi ilmu pengetahuan. Banyak konsep matematika yang membantu disiplin ilmuilmu lainnya, dan tidak sedikit memberikan kontribusinya terhadap perkembangan teknologi dan sains serta dapat menciptakan bentuk kehidupan sosial budayanya. Matematika perlu diberikan untuk membekali peserta didik dengan kemampuan berpikir nalar. Kemampuan berfikir nalar tersebut diperlukan agar peserta didik dapat memiliki kemampuan memperoleh, mengelola, dan memanfaatkan infomasi untuk bertahan hidup pada keadaan yang selalu berubah, tidak pasti, dan kompetitif.

Pengembangan SDM saat ini harus di titik beratkan pada kemampuan berpikir, yang melibatkan pemikiran krirtis, sistematis, logis, dan kreatif. Dalam suatu proses kegiatan berpikir memerlukan pemahaman dan kemampuan bernalar tentang masalah yang berhubungan dengan sesuatu yang sedang dipikirkan. Penalaran (reasoning) merupakan salah satu aspek dari kemampuan berpikir matematik tingkat tinggi yang harus dikuasai peserta didik sesuai dengan kurikulum yang berlaku.

Melalui berpikir nalar manusia dapat berkreasi dan menciptakan teknologi yang dapat mempermudah kehidupannya sehingga tercipta manusia - manusia yang berprestasi untuk mewarnai kehidupan maupun perkembangan pengetahuan di dunia ini. Mahasiswa berprestasi dalam menempuh pendidikannya dipengaruhi banyak faktor baik dari dalam maupun dari luar dirinya. Salah satu yang mungkin berkontribusi dalam prestasi belajar mahasiswa adalah kemampuan berpikir nalar matematisnya. Dengan daya nalar ini manusia terus berkembang dan meningkatkan kemampuannya dalam beradaptasi dengan lingkungan yang dinamis dan berubah secara kontinu. Daya nalar merupakan modal utama dalam mempersiapkan mereka menghadapi persaingan yang sangat ketat di masa datang. Semakin tajam daya nalar seseorang maka ia akan semakin mampu menghadapi tantangan hidup.

Tujuan penelitian ini dirumuskan secara spesifik sebagai berikut: Untuk mengetahui kemampuan berfikir nalar matematis baik secara induktif maupun deduktif mahasiswa program studi pendidikan matematika, untuk mengetahui bagaimana prestasi belajar mahasiswa program studi pendidikan matematika, untuk mengetahui berapa besar kontribusi kemampuan berfikir nalar matematika terhadap prestasi belajar mahasiswa program studi pendidikan matematika.

Uraian singkat di atas mendorong munculnya permasalahan penelitian yaitu apakah kemampuan berpikir nalar matematis mahasiswa tergolong kategori tinggi? Ke dua apakah prestasi belajar mahasiswa pendidikan matematika berdasarkan kategori yudisium yang berlaku tergolong memuaskan? Dan masalah terakhir adalah bagaimanakah kontribusi kemampuan berpikir nalar terhadap prestasi belajar mahasiswa program studi pendidikan matematika unsil?.

Selanjutnya sebagai landasan teoritis penelitian ini akan dibahas kemampuan berpikir nalar dan prestasi belajar mahasiswa. Kemampuan Berfikir Nalar. Istilah penalaran adalah terjemahan dari kata reasoning yang bermakna proses berpikir untuk menarik kesimpulan logis berdasarkan fakta dan sumber yang relevan (Shurter dan Pierce dalam Sumarmo, 1987; Suherman dan Winataputra, 1993; Hudojo, 1988). Selain itu, menurut The Third International Mathematics and Sciences Study (TIMSS) tahun 2003 (Mullis, et al., 2003) penalaran matematika meliputi kecakapan logis dan berpikir sistematis. Matematika melatih cara berfikir dan bernalar dalam menarik kesimpulan, misalnya melalui kegiatan penyelidikan, eksplorasi, eksperimen, menunjukan kesamaan, perbedaan, konsisten dan inkonsistensi. Selanjutnya Shurter dan Pierce (Dahlan, 2004) menjelaskan bahwa secara 
garis besar terdapat dua jenis penalaran yaitu penalaran deduktif dan induktif.

Penalaran deduktif adalah cara menarik kesimpulan individual atau khusus dari hal-hal yang bersifat umum. Penalaran deduktif dimaksudkan kemampuan menilai atau membuktikan suatu argument berfikir adalah falid/sah dalam penarikan kesimpulannya. Berfikir nalar sederhana yang mempunyai fungsi pokok dalam deduksi adalah kondisional dan silogisme. Penalaran kondisional berbentuk hubungan antara kondisi atau pernyataan yang dinyatakan dalam hubungan “ jika p, maka q" . p disebut anteseden dan q disebut konsekuen. Beberapa jenis penalaran kondisional diantaranya : (1) memperkuat anteseden, (2) memperkuat konsekuen, (3) menyangkal anteseden, (4) menyangkal konsekuen. Dalam penalaran kondisional proposisi yang menyatakan kondisi disebut anteseden (antecedent, sering juga implicans, tidak begitu sering: protasis), sedang anggota yang tergantung kepada anteseden disebut konsekuens (consequent, sering juga implicate, tidak begitu sering: apodosis). Argumen matematis ini dinyatakan valid apabila konsekuen terbukti benar harus didahului oleh terpenuhinya kondisi yang menjadi sarat yaitu antesedennya harus benar.Silogisme. Penalaran deduktif pada dasarnya bentuk berpikir nalar matematis yaitu menarik suatu simpulan yang didasarkan dari sesuatu kebenaran umum baik kebenaran tanpa dibuktikan (aksioma) maupun dibuktikan terlebih dahulu. Kita juga dapat membentuk formula konklusi yang merupakan kombinasi dari dua bagian (term) yang secara terpisah terdapat dalam premis premis maupun konklusinya. Argumen demikian dikenal dengan nama silogisme.

Sebagai contoh : Semua manusia adalah fana. Sokrates adalah manusia. Jadi Sokrates adalah fana

Inferensi argument di atas adalah silogisme yang valid secara standar dirumuskan dengan premis mayor yang ditulis paling awal, sebelum premis minor dan konklusinya.
Penalaran induktif adalah cara menarik kesimpulan yang bersifat umum dari kasuskasus yang bersifat individual. Soekadijo (1999) mengatakan bahwa penalaran induktif terdiri dari tiga jenis yaitu analogi, generalisasi dan kausalitas. Menurut Mundiri (2000: 137) analogi adalah membandingkan dua hal yang berlainan berdasarkan keserupaannya, kemudian menarik kesimpulan atas dasar keserupaan tersebut. Ada dua analogi yaitu analogi induktif dan analogi deklaratif atau analogi penjelas. Analogi dapat dimanfaatkan sebagai penjelasan atau sebagai dasar penalaran. Analogi merupakan dua hal yang berlainan, yang satu bukan yang lain, dan dua hal yang berlainan itu dibandingkan yang satu dengan yang lainnya. Dalam hal ini yang dicari adalah persamaan di antara dua hal yang berbeda, dengan menarik kesimpulan atas dasar persamaan itu.

Generalisasi adalah pemaparan tentang hubungan beberapa konsep (pengertian) yang diterapkan dalam situasi yang lebih umum. Penalaran ini mencakup pengamatan contoh-contoh khusus dan menemukan pola atau aturan umum. Penalaran generalisasi dapat pula diartikan memperluas domain yang dihasilkan dari pemikiran nalara matematis dan pemecahan masalah yang dapat diaplikasikan dengan menyatakan kembali hasil hasil yang lebih umum. Sebagai contoh: hasil kali dua bilangan ganjil adalah bilangan ganjil. Hasil bilangan ganjil ditemukan melalui pengamatan dari beberapa contoh khusus. Kesimpulan dari contoh khusus tersebut merupakan kesimpulan umum. Contoh kedua yaitu pengamatan yang dilakukan terhadap barisan bilangan melalui kemampuan nalar yang dimiliki peserta didik menemukan pola umum yang melandasi barisan bilangan tersebut.

Sedangkan penelaran induktif yang lain adalah kausalitas atau hubungan sebab akibat. Ini sering digunakan dalam ilmu pengetahuan maupun kehidupan sehari hari. Schwartz (Dahlan, 1994:39) mendefinisikan kausalitas sebagai suatu keadaan yang saling berhubungan di mana keadaan yang satu 
dipengaruhi oleh keadaan yang lain sederhananya yang satu sebagai penyebab kejadian (cause) sedangkan yang lain sebagai kejadian akibat (effect). Sebagai contoh pada transformasi dilatasi apabila pengali diperbesar mengakibatkan hasil dilatasinya juga membesar.

The Third International Mathematics and Sciences Study (TIMSS) tahun 2003 (Mullis, et al., 2003) menyatakan bahwa terdapat empat domain kognitif yang harus dimiliki siswa. Keempat domain tersebut adalah memahami fakta dan prosedur, menggunakan konsep, menyelesaikan masalah rutin, dan penalaran. Penalaran matematika meliputi kecakapan logis dan berpikir sistematis. Penalaran tersebut meliputi penalaran intuitif dan induktif yang berdasarkan pada pola-pola dan aturan-aturan yang dapat digunakan dalam menyelesaikan masalah non-rutin. Masalah non-rutin adalah masalah yang tidak dikenal oleh siswa, yang prosedur penyelesaiannya memerlukan perencanaan, tidak sekedar menggunakan rumus, teorema atau dalil. Masalah non rutin tersebut memerlukan pengetahuan dan keterampilan yang lebih tinggi untuk menyelesaikannya dibandingkan dengan menyelesaikan masalah yang sebelumnya telah dipelajari. Masalah non rutin tersebut mungkin murni matematika atau mungkin dalam kehidupan sehari-hari. Kedua tipe masalah non rutin tersebut, meliputi transfer pengetahuan dan keterampilan ke dalam situasi baru, dan interaksi antarketerampilan bernalar.

Kemampuan penalaran matematis sangat penting bagi peserta didik karena berperan dalam: 1) melatih peserta didik dalam proses berpikir kritis dan logis (Shurter dan Pierce dalam Sumarmo, 1987; Suherman dan Winataputra, 1993; Hudojo, 1988); 2) menuntun peserta didik untuk menyusun dan menguji konjektur, menyusun pembuktian (Sumarmo, 2002a); Mullis, et. al. 2003 3) menuntun siswa untuk dapat menganalisis, mengevaluasi, menggeneralisasi, mensintesis/mengintegrasikan, menyelesaikan masalah non-rutin, dan menjustifikasi/membuktikan (Mullis, et al., 2003). Untuk mengembangkan kemampuan penalaran matematik dapat dilakukan dengan berbagai jenis aktivitas, antara lain: 1) pemberian penalaran yang dimulai sejak usia dini (Baroody, 1993); 2) dalam pembelajaran guru hendaknya berusaha agar siswa tidak hanya trampil mengaplikasikan konsep atau rumus saja, tetapi lebih didorong ke arah pencapaian tingkat penalaran yang lebih tinggi (Sumarmo, 1987); dan 3) soal-soal yang diberikan beragam dan soal tidak rutin yaitu masalah yang tidak dikenal oleh siswa, yang prosedur penyelesaiannya memerlukan perencanaan, tidak sekedar menggunakan rumus, teorema atau dalil (Mullis, et. al., 2003).

Prestasi Belajar Mahasiswa Istilah prestasi belajar terdiri dari dua suku kata, yaitu prestasi dan belajar. Istilah prestasi di dalam Kamus Ilmiah Populer (Adi Satrio, 2005: 467) didefinisikan sebagai hasil yang telah dicapai. Noehi Nasution (1998: 4) menyimpulkan bahwa belajar dalam arti luas dapat diartikan sebagai suatu proses yang memungkinkan timbulnya atau berubahnya suatu tingkah laku sebagai hasil dari terbentuknya respon utama, dengan syarat bahwa perubahan atau munculnya tingkah baru itu bukan disebabkan oleh adanya kematangan atau oleh adanya perubahan sementara karena sesuatu hal. Sementara itu Muhibbin Syah (2008: 90-91) mengutip pendapat beberapa pakar psikologi tentang definisi belajar, di antaranya adalah Skinner, seperti yang dikutip Barlow dalam bukunya educational Psychology : The Teaching-Learning Process, berpendapat bahwa belajar adalah suau proses adaptasi atau penyesuaian tinkah laku yang berlangsung secara progresif (a process of progressive behavior adaptation). Berdasarkan eksperimennya, B.F. Skinner percaya bahwa proses adaptasi tersebut akan mendatangkan hasil yang optimal apabila ia diberi penguat (reinforce).

Adapun pengertian belajar secara kualitatif (tinjauan mutu) ialah proses 
memperoleh arti-arti dan pemahamanpemahaman serta cara-cara menafsirkan dunia disekeliling pelaku belajar. Belajar dalam pengertian ini difokuskan pada tercapainya daya pikir dan tindakan yang berkualitas untuk memecahkan masalah-masalah yang kini dan nanti dihadapi pelaku belajar. Abu Muhammad Ibnu Abdullah (2008), beliau mengutip pendapat beberapa pakar dalam menjabarkan pengertian belajar, di antaranya adalah W.S. Winkel (1991: 36) dalam bukunya yang berjudul Psikologi Pengajaran. Menurutnya, pengertian belajar adalah suatu aktivitas mental/psikis yang berlangsung dalam interaksi aktif dengan lingkungan yang menghasilkan perubahan-perubahan dalam pengetahuan, pemahaman, keterampilan, dan nilai-nilai sikap. Perubahan itu bersifat secara relatif konstan dan berbekas".

Sedangkan Mahfud Shalahuddin (1990: 29) dalam buku: Pengantar Psikologi Pendidikan, mendefinisikan belajar sebagai suatu proses perubahan tingkah laku melalui pendidikan atau lebih khusus melalui prosedur latihan. Perubahan itu sendiri berangsurangsur dimulai dari sesuatu yang tidak dikenalnya, untuk kemudian dikuasai atau dimilikinya dan dipergunakannya sampai pada suatu saat dievaluasi oleh yang menjalani proses belajar itu.

Bertolak dari berbagai definisi yang telah diuraikan para pakar tersebut, secara umum belajar dapat dipahami sebagai suatu tahapan perubahan seluruh tingkah laku inividu yang relatif menetap (permanent) sebagai hasil pengalaman. Sehubungan dengan pengertian itu perlu ditegaskan bahwa perubahan tingkah laku yang timbul akibat proses kematangan (maturation), keadaan gila, mabuk, lelah, dan jenuh tidak dapat dipandang sebagai hasil proses belajar. Sehingga dapat diambil sebuah kesimpulan bahwa belajar adalah suatu proses perubahan tingkah laku individu yang relatif menetap (permanent) sebagai hasil atau akibat dari pengalaman dan interaksi dengan lingkungan yang melibatkan proses kognitif, afektif dan psikomotor.
Prestasi belajar atau hasil belajar menurut Muhibbin Syah, sebagaimana yang dikutip oleh Abu Muhammad Ibnu Abdullah (2008) adalah "taraf keberhasilan murid atau santri dalam mempelajari materi pelajaran di sekolah atau pondok pesantren yang dinyatakan dalam bentuk skor yang diperoleh dari hasil tes mengenai sejumlah materi pelajaran tertentu". Dalam Kamus Besar Bahasa Indonesia, dikemukakan bahwa yang dimaksud dengan prestasi belajar adalah "penguasaan pengetahuan atau keterampilan yang dikembangkan oleh mata pelajaran, lazimnya ditunjukan dengan nilai tes atau angka nilai yang diberikan oleh guru". Berdasarkan uraian-uraian tersebut dapat disimpulkan bahwa prestasi belajar adalah tingkat keberhasilan yang dicapai dari suatu kegiatan atau usaha yang dapat memberikan kepuasan emosional, dan dapat diukur dengan alat atau tes tertentu.

\section{METODE PENELITIAN}

Penelitian ini menggunakan metode dokumentasi, deskriptif, regresi korelasional. Pemilihan metode ini didasarkan atas pertimbangan waktu terjadinya masalah dan juga adanya tujuan mendeskripsikan pokok masalah dan hasil penelitian secara apa adanya. Untuk kepentingan itu diperlukan rancangan penelitian. Subjek penelitian, teknik pengumpul data, teknik analisis data dan jadwal penelitian yang jelas. Penelitian ini dirancang berdasarkan desain penelitian kuantitatif. Subjek penelitian diambil secara purposive random sampling. Variabel $\mathrm{X}$ sebagai kemampuan berfikir nalar matematis dan variabel $Y$ sebagai prestasi belajar mahasiswa. Pengumpulan data dilakukan dengan observasi dan melaksanakan tes tulis kemampuan berfikir nalar matematis serta dokumentasi IPK mahasiswa program studi pendidikan matematika.

Pengolahan data dengan cara menganalisis dan mendeskripsikan data variabel $\mathrm{X}$ dibuat dalam kategori interval yakni kategori berfikir nalar rendah, sedang dan tinggi. Selanjutnya mengolah dan analisis data variabel $\mathrm{Y}$ dibuat 
kedalam kategori sesuai pedoman akademik universitas siliwangi. Selanjutnya mencari hubungan fungsional antara 2 variabel $\mathrm{x}$ dan $\mathrm{y}$ (regresi) dan koefesien korelasinya. Mencari derajat kontribusi dengan menghitung koefisien $r$ dan $r^{2}$. Terahir menguji hipotesis dengan menggunakan SPSS versi 20.

Populasi dalam penelitian ini adalah seluruh mahasiswa di program studi pendidikan matematika Universitas Siliwangi. Degan pertimbangan bahwa mahasiswa pada tingkat

HASIL PENELITIAN DAN PEMBAHASAN

Deskripsi kemampuan berpikir nalar akhir sudah mengambil dan menempuh banyak mata kuliah serta tingkat kematangan sudah dianggap mumpuni. Penarikan sampel dilakukan dengan menggunakan teknik random sampling menurut kelas. Terpilih kelas $\mathrm{C}$ dengan jumlah mahasiswa 41 orang. Instrumen yang digunakan dalam penelitian ini berupa seperangkat soal tes pilihan ganda untuk menggali penalaran mahasiswa sebanyak 20 soal.

Tabel 1

Kemampuan Berfikir Nalar Matematis

\begin{tabular}{cccl}
\hline Skor & Frekuensi & Persentase (\%) & \multicolumn{1}{c}{ Kategori } \\
\hline $0-40$ & 0 & $0 \%$ & Kurang \\
\hline $41-60$ & 3 & $7,32 \%$ & Cukup \\
\hline $61-80$ & 28 & $68,29 \%$ & Baik \\
\hline $81-100$ & 10 & $24,39 \%$ & Sangat Baik \\
\hline Jumlah & $\mathbf{4 1}$ & $\mathbf{1 0 0} \%$ & \\
\hline
\end{tabular}

Kemampuan Berfikir Nalar sangat baik serta tidak ada satupun yang berkategori cukup sebanyak 7,32 \%, kategori berkemampuan nalar kurang. Deskripsi baik $68,29 \%$ sisanya $24,39 \%$ berkategori prestasi belajar dapat dilihat dari tabel berikut.

Tabel 2

Prestasi Belajar (IPK)

\begin{tabular}{cccl}
\hline Skor & Frekuensi & Persentase (\%) & \multicolumn{1}{c}{ Predikat } \\
\hline $0,00-1,99$ & 0 & $0 \%$ & Kurang Memuaskan \\
\hline $2,00-2,75$ & 9 & $21,95 \%$ & Memuaskan \\
\hline $2,76-3,50$ & 27 & $65,85 \%$ & Sangat Memuaskan \\
\hline $3,51-4,00$ & 5 & $12,20 \%$ & Dengan Pujian \\
\hline Jumlah & $\mathbf{4 1}$ & $\mathbf{1 0 0} \%$ & \\
\hline
\end{tabular}

Berdasarkan data pada Tabel 2 menunjukan bahwa 21,95 \% memuaskan, 65,85\% sangat memuaskan dan sisanya hanya $12,20 \%$ dengan pujian. Statistik Kemampuan Berpikir Nalar dan Prestasi Belajar

\begin{tabular}{lccc}
\hline & \multicolumn{3}{c}{ Statistics } \\
\hline & $\mathrm{X}$ & $\mathrm{Y}$ \\
\hline \multirow{2}{*}{$\mathrm{N}$} & Valid & 41 & 41 \\
\cline { 2 - 4 } & Missing & 0 & 0 \\
\hline Mean & & 75.9756 & 3.0639 \\
\hline
\end{tabular}

\begin{tabular}{lcc}
\hline & \multicolumn{3}{c}{ Statistics } \\
\hline & $\mathrm{X}$ & $\mathrm{Y}$ \\
\hline Median & 75.0000 & 2.9700 \\
\hline Mode & 70.00 & $2.75^{\mathrm{a}}$ \\
\hline Std. Deviation & 10.19923 & .35813 \\
\hline Variance & 104.024 & .128 \\
\hline Range & 45.00 & 1.40 \\
\hline Minimum & 55.00 & 2.46 \\
\hline Maximum & 100.00 & 3.86 \\
\hline
\end{tabular}


Dari 41 subjek penelitian diperoleh data terendah 55 untuk berpikir nalar dan IPK 2,46 sedangkan tertinggi berpikir nalarnya 95 dan IPK 3,86. Rerata untuk berpikir nalar sebesar 75.98, rerata untuk IPK sebesar 3.06 dengan simpangan baku berturut - turut 10,20 dan 0,36 . Melalui pengujian satu rata - rata dengan uji t diperoleh bahwa simpulan kemampuan berpikir nalar pada mahasiswa tergolong kategori baik dan prestasi belajar mahasiswa tergolong sangat memuaskan.

Hubungan fungsional antara kemampuan berpikir nalar dengan IPK mahasiswa ditunjukan oleh : persamaan regresi $Y^{\prime}=0,835+0,29 x$ artinya untuk setiap perubahan pada kemampuan daya nalar rata rata satu satuan maka akan terjadi peningkatan IPK sebesar 0,29. Sedangkan koefesien korelasi antara kemampuan berpikir nalar matematis dan IPK didapat $\mathrm{r}=0,84$. Berdasarkan kriteria korelasi nilai koefisien tersebut termasuk pada kreiteria korelasi positif sangat tinggi. Sehingga hubungan antara berpikir nalar dan prestasi belajar adalah erat atau kuat berarti jika berpikir nalar tinggi maka prestasi belajar juga tinggi. Kontribusi kemampuan berfikir nalar matematis terhadap prestasi belajar mahasiswa program studi pendidikan matematika yang dinyatakan dengan $r^{2}=0,71$ artinya faktor kemampuan daya nalar matematis menentukan indeks prestasi belajar mahasiswa sebesar $71 \%$ sisanya ditentukan oleh faktor lainnya.

\section{KESIMPULAN DAN SARAN}

Kesimpulan yang dapat ditarik dari penelitian ini adalah Kemampuan Berfikir Nalar Matematis tergolong baik, Indeks Prestasi Komulatif mahasiswa pendidikan matematika tergolong sangat memuaskan dan Kontribusinya kemampuan nalar matematis terhadap Prestasi Belajar Mahasiswa tergolong sangat tinggi.

Berdasarkan temuan pada penelitian ini, penulis kemukakan saran sebagai berikut : bagi mahasiswa disarankan untuk selalu meningkatkan kemampuan berpikir nalar dengan harapan indeks prestasinya komulatifnya akan meningkat. Bagi pendidik dalam setiap pembelajaran mengembangkan pembelajaran yang dapat meningkatkan kemampuan penalaran peserta didiknya. Bagi peneliti agar melaksanakan penelitian yang relevan yang lebih rinci dan bermanfaat bagi dunia pendidikan.

\section{DAFTAR RUJUKAN}

Alamsyah. 2000. Suatu pembelajaran untuk meningkatkan kemampuan penalaran analogi matematika. Tesis pada PPS UPI (tidak diterbitkan). Bandung.

Dahlan, J. A. 2004. Meningkatkan kemampuan penalaran dan pemahaman matematika siswa sekolah lanjutan tingkat pertama melalui pendekatan pembelajaran open ended. Disertasi Doktor pada PPS UPI (tidak diterbitkan). Bandung.

Hudojo, H. 1990. Pengembangan kurikulum matematika dan pelaksanaannya di depan kelas. Usaha Nasional. Surabaya.

Karli, H. dan S.M. Yuliariatiningsih. 2002. Implementasi kurikulum berbasis kompetensi. Model-model pembelajaran. Bina Media Informasi. Bandung

Mullis, I.V.S, Martin, M.O., Gonzalez, E.J. and T.A. Smith. 2000. TIMMS 1999. International mathematics report. The International Study Center Bortox College, Lynch School of Education.

Mullis, I.V.S, Martin, M.O., Gonzalez, E.J., Smith, T.A., Garden, R.A., Gregory, K.D., Chrostowki, S.J., dan O'Connor, K.M. 2003. TIMSS. Assessment Frameworks and Specifications 2003. Trend in mathematics and science study. The International Study Center Bortox College, Lynch School of Education. Mundiri. 2002. Logika. Karya Grafindo Persada. Jakarta. 
Nasution, N. 1997. Materi psikologi pendidikan. Depdikbud. Jakarta

Priatna, N. 2002. Kemampuan penalaran induktif dan deduktif serta kaitannya dengan pemahaman matematika siswa kelas 3 SLTP Negeri di Kota Bandung. Disertasi pada PPS UPI Bandung (tidak diterbitkan).

Ruseffendi, E.T. 1994. Dasar-Dasar Penelitian Pendidikan dan Non Eksakta Lainnya. : IKIP Semarang Press. Semarang.

Sudijono, A. 1996. Pengantar evaluasi pendidikan. PT. Raja Grafindo Persada. Jakarta

Sudjana.1992. Metoda statistika, edisi ke-5. Tarsito. Bandung

Suherman, E. dan U. Winataputra. 1993. Strategi belajar mengajar matematika. Depdikbud. Jakarta

Suherman, E., dkk. 2001. Strategi pembelajaran matematika kontemporer. JICA. Bandung

Suriasumantri, J.S. 1996. Filsafat ilmu. Sebuah pengantar populer. Pustaka Sinar Harapan. Jakarta

Sumarmo, U. 1987. Kemampuan pemahaman dan penalaran matematik siswa SMA dikaitkan dengan kemampuan penalaran logik siswa dan beberapa unsur proses belajar mengajar. Disertasi pada Fakultas Pasca Sarjana IKIP Bandung. (Tidak diterbitkan).

Sumarmo, U. 2000a. "Hand outs proses belajar dan pemahaman materi kuliah." Disajikan pada Lokakarya Peran Pedagogi dalam Peningkatan Proses Pembelajaran TPB ITB, tanggal 4 Desember 2000.

Sumarmo, U. 2000b. Kecenderungan pembelajaran matematika pada abad 21. Makalah pada Seminar Pendidikan Matematika FPMIPA, UPI Bandung.

Sumarmo, U. 2002a. “Alternatif pembelajaran matematika dalam menerapkan kurikulum berbasis kompetensi."
Makalah disajikan pada Seminar Tingkat Nasional FPMIPA UPI Bandung. (Tidak diterbitkan).

Sumarmo, U. 2002b. "Pembelajaran matematika untuk mendukung pelaksanaan kurikulum berbasis kompetensi." Makalah disajikan pada pelatihan guru MTs, Agustus 2002 di Bandung.

Sutiarso, S. 2000. Problem posing, strategi efektif meningkatkan aktivitas siswa dalam pembelajaran matematika. Tidak diterbitkan. Bandung.

Suzana, Y. 2003. Meningkatkan kemampuan pemahaman dan penalaran matematika siswa SMU melalui pembelajaran dengan pendekatan metakogtnitif. Tesis pada PPS UPI Bandung (tidak diterbitkan).

Wahyudin. 1999. Kemampuan guru matematika, calon guru matematika, dan siswa dalam mata pelajaran matematika. Bandung: Disertasi Doktor pada PPS UPI Bandung (tidak diterbitkan). 